\title{
Research on Education Reform of Electronic Information Specialty in Local Colleges
}

\author{
Fang Ruan, ${ }^{1,2}$ Hebin Cheng ${ }^{1,2, *}$ \\ ${ }^{1}$ School of Mechatronics, \\ ${ }^{2}$ Key Laboratory of Public Security Management Technology in Universities of Shandong (Shandong Management University) \\ Shandong Management University, \\ 250001 Jinan, China \\ warmmind@163.com
}

\begin{abstract}
Many issues exist in education mechanisms of local colleges, for example, the teaching purpose is not clear, the curriculum is not reasonable and the teaching idea is not perfect. To address these issues, this paper focused on education reform of the talent training mechanism in electronic information, put forward the professional training program by integration with the enterprise demand. The overall quality of students has been raised through the curriculum setup, tutor system counseling, academic competition platform construction, open laboratory, research projects and other measurements, and finally improves the students' application ability and basic quality in the two-way architecture of theory and practice education.
\end{abstract}

Keywords-Talent training; Electronic information; Innovative education; Education reform

\section{INTRODUCTION}

With the rapid development of internet, computer technology and electronic information technology, the information technology has already become the pillar of the social development, which greatly stimulates the demand of talent of electronic information specialty in the social market. Moreover, it also makes the electronic information specialty favorable in the field of education. Therefore, the talent demand for electronic information specialty will not be met in the next period.

Along with the market demand for talents in electronic information specialty is the "three high" requirements of high skill, high quality and high degree proposed by the enterprises and society. Furthermore, these enterprises favor the students with the applied creative ability and strong practical ability, and "zero joint" type without too much adaption [1].

\section{EXISTING PROBLEMS IN LOCAL EDUCATION SYSTEM}

Local colleges focus on training and transporting talents for serving the development of local economy; however, these colleges are restricted by their teaching conditions, cultural accumulation and comprehensive strength, thus there is a contradiction between the trained talents and the market demand [2]. Especially for the students of electronic information engineering, they lack of experimental teaching conditions and their basic ability depends on theory teaching, which leads to their poorer comprehensive practice quality and weaker technology innovation ability. Consequently, the innovation practice ability of the students from these colleges fails to meet the requirements of the enterprise and society [3]. As the graduates do not meet the enterprise standards, the enterprises cannot recruit high-quality graduates and a large number of graduates cannot find jobs, resulting in the "employment difficulties" of graduates and "talent shortage" of enterprises. This situation will directly hinder the local economic development.

\section{THE EDUCATION REFORM ROAD OF ELECTRONIC INFORMATION SPECIALTY}

In order to alter such a difficult situation, we paid close attention to education and solved the problem from the root. Additionally, local colleges ought to develop a talent training program for the enterprise requirements, build and refine the teaching and training system of electronic information specialty Accordingly, many experts and scholars expressed their viewpoints and suggestions from different angles. Despite some extent of the success, however, many issues still exist in the majority of electronic information specialty education teaching system [4-5]:

(1) The curriculum structure setup was not reasonable, and the teaching effect was not ideal. The curriculum of electronic information specialty set by colleges was too outdated, and much knowledge could not keep up with the development of the times, some social professional courses urgently needed were not introduced timely, the knowledge that students learned in the classroom lagged far behind the current society, the students could not adapt well with the enterprise and they had to be trained again.

(2) The limitations of the teaching mode were too strong Though diverse teaching modes were advocated, many colleges were confined to "classroom teaching" because of the problems of faculty, teaching instruments and equipment. This kind of education was too traditional, students had been in a passive state of learning and they cannot learn autonomously. 
(3) Practical innovation and application ability was weak. Because many colleges were restricted by the limited teaching conditions and facilities, the students engaged in less teaching practice and paid little attention in thought. They lacked of ability to solve practical problems, thus their comprehensive practical skills and quality could not be strengthened.

(4) The university education and the market demand for talent disjointed. This was an urgent problem to be dealt with. Many colleges were confined to textbooks, and their teaching content could not keep up the pace of social development. As a result, the skills and quality required for the talents of electronic information specialty by the enterprises were ignored, leading to the isolation, occlusion and fragmentation of education.

As educators, one ought to train the comprehensive ability level more contrapuntally and purposefully. Apart from improvement of their own knowledge structure, they should follow the pace timely and pay close attention to the practice teaching of students. They need to combine the theoretical knowledge acquired by students with experiment and practice, aiming to cultivate more innovative talents for society and enterprises.

\section{EDUCATION REFORM IDEAS OF ELECTRONIC INFORMATION SPECIALTY}

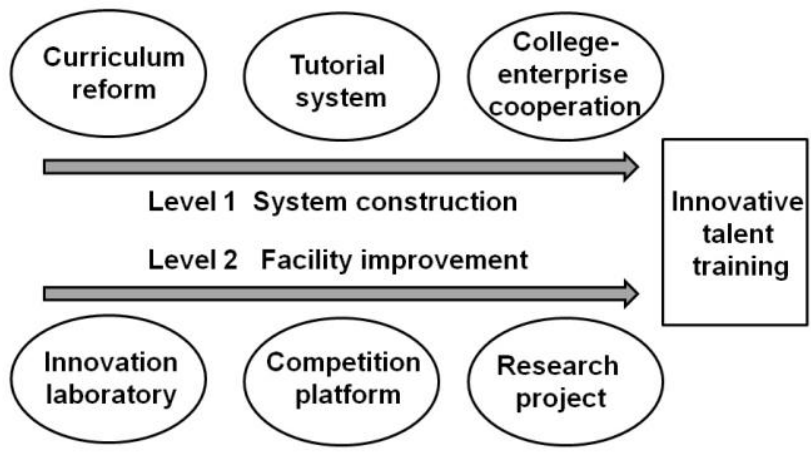

Fig. 1 Schematic diagram of education reform paths of electronic information specialty.

By means of the two lines of system construction and facility improvement (as shown in Fig.1), innovative educational reform measures were described as follows:

\section{A. Conducting the reform of curriculum teaching mode}

By adopting the curriculum teaching mode, we optimized the teaching content and organizational structure, reduced the cost of teaching operation, improved the efficiency of resource utilization, and speeded up the formation of professional clusters, teaching team and excellent course advantages. According to the training objectives, knowledge content and professional orientation, teachers chose the teaching content, and paid attention to the latest scientific achievements and put their own research achievements into teaching. On the base of the logical relationship, the teachers divided and integrated the teaching content rationally, which were classified into 5 major curriculums of basic skills, electronic circuit, program design, network communication and comprehensive type. Each class was relatively independent, and the relevant teaching team was responsible for teaching quality standards, exquisite course construction, as well as the implementation of specific teaching.

\section{B. Constructing tutorial system}

The matching problem of personal ability and the teaching process has always been popular. Foreign scholars had also carried out research on this issue, such as DonHamachek (DonHamachek, 1969), who thought the teacher's ability in classroom teaching should include flexibility, personal feeling, questioning skills, empathy, experimental attitude, rich knowledge in specialty, definite test program, helping students, appreciating students and easygoing [6]. Some domestic scholars believed that we ought to establish training model with ability training as the core, carry out the teaching activities with the ability training as the goal, and construct the evaluation system to train the teaching ability of teachers based on the ability assessment [7]. Colleges had a number of high-quality, highly educated teacher reserves, allocated mentors rationally and targetedly, and realized the highly efficient utilization of teaching resources. The colleges provided students with more professional and much stronger teaching staff, not only teaching students theoretical knowledge and practical skills, but also cultivating students' economic quality, communication, association, organization and other aspects of quality. Using the two-way selection mode, some part of the students as research force were selected and participated in the teacher's research projects, and carried out the corresponding scientific research work with the teacher's research platform under their guidance. As long as the students finished the basic theory courses and practical training, the teachers and student met through lectures or professional symposia, which intended to introduce the teaching, scientific researches and engineering experience of each teachers and specialty directions. According to the students' interest and long-term program, the teachers organized the students to choose the specialty direction and tutor, and the professional tutor gave comprehensive guidance of the next two years' course learning and engineering practice, including literature review, topic selection, project practice, technological innovation and graduation thesis. At the fourth year, the students entered the teacher's research group officially to carry out research work and wrote the graduation thesis or academic papers by combination of their research work.

\section{Establishing open innovation talents training laboratory}

Focusing on the interest of students, an innovative, flowing, and open laboratory was established that served for students' autonomous learning and self-management. The teachers guided the students to dap out of the confinement of the classroom teaching, and encouraged the students to observe more and fins out the existing problems from their own life, to think more and think out the way to solve the problem; to practice more and analyze the problem using their professional knowledge. The teachers provided hardware facilities, theoretical training, and technical support for students' innovative practice, settling the worries of students. The laboratory adopted the flowing mode of talent training, and the students managed the laboratory autonomously; experienced 
higher grade students took over the laboratory management, and the students learned and communicated with each other. The colleges encouraged students to actively participate in the learning and communication in the laboratory. This teaching mode is novel and flexible, and the students can focus on their own interests, which plays great role in developing the quality and stimulating potential of the students.

\section{Building a new talent training mode thorough college- enterprise cooperation}

To serve the community as the starting point and goal, the cooperation between college and excellent enterprise was encouraged. The teaching reform was actively promoted, the students were advised to enter enterprise from college, and the enterprises were encouraged to participate in the teaching system reform together. In the enterprises, they provided students with talents training base of electronic information for innovative practice, affording students professional hardware facilities and technical guidance. In the colleges, the professional instructors in electronic information combined their own scientific research and local enterprise, and set the scientific cooperation project. Under the two pronged "collegeenterprise" teaching mode, the training talents met well with the talents urgently needed by the enterprise, and thus the talent training mode of electronic information that adopted well in college and enterprise was constructed. Through the joint organization of college students on or off campus internship training with the cooperated enterprises, it helped the students to experience the true scene and research needs, master the latest technology and key points of the frontline, leads the students to pay more attention to the enterprise standard working process and the normative development, improves the overall technical level of college students, cultivates the technological talent that industry really needs, and finally provided the enterprises and society with large number of senior technical talents that adopt enterprise mechanism and have strong applied ability.

\section{E. Building competition platform to enhance innovation ability}

(1) The college actively organized innovative science and technology competition, encouraged students to participate in it established physical and creative skills competition, mobilized the enthusiasm of the students by setting awards and prizes, and encouraged the students to build their own team. Through arranging the work and cooperating with each other, the mutual help not only endowed the students with much knowledge, but also brought them friendship and growth.

(2) The college encouraged students to go out of the campus, and actively participated in various provincial and national science and technology innovation contest, did propaganda work, supported them to participate in these games, and provided technical and theoretical guidance, offered the manpower and financial support to the maximum extent, and broadened their horizons. In these ways, the technical skills could be raised to a higher level.

\section{F. Cultivating college students' innovative practical ability driven by research project}

The innovation and practice ability of college students was raised on the basis of the talent training goal. Through refining the training program, the teachers updated the teaching contents timely and improved the innovation teaching methods, which displayed great advantages and gained wonderful results The scientific research program was set up by the college or derived from the project of the teachers, which was then followed by the project team composed of college students. Guided by the rule of "The project as the mainline, teachers as leading factor and college students as the main body", the college students gained theoretical knowledge and improved their own practical ability. According to the actual situation, the project design and test scheme were worked out.

With the project as the starting point, the college students' active participation and a sense of accomplishment was enhanced; this not only stimulated students' interest in learning, improved their comprehensive quality and practical ability, but also cultivated their team consciousness. Through scientific research projects, the team of college students gained mutual encouragement and common progress, and the college students trained under this education mode met the social and business demand for talents. The training mode of innovation ability driven by project was important for students, colleges and enterprises.

\section{SUMMARY}

Taking our college as an example, the innovation practice education of electronic information specialty has achieved initial results. Our school of mechanical and electrical engineering established the laboratories for innovative practice, and set up a group of complementary innovation team. With the support of the school, the team has successfully completed the research projects such as "intelligent safety helmet", and the graduates have already gone out to their working positions. The college held the annual science and technology innovation contest for all the students, which attracted many students to participate in, and had also made remarkable achievements in the innovation of practice teaching.

Confined to a variety of factors, the research on the education reform of the electronic information specialty encountered more problems on its developing roads. The education reform of electronic information specialty could not be accomplished overnight, and the talents training manner need to be constantly improved, which is inescapably responsible for the students themselves, colleges, enterprises and society. We need to strengthen our confidence, constantly optimize the curriculum, construct scientific training system, accelerate the construction of college practical teaching base, build a teaching system fundamentally with practice and innovation as the core, and improve the students' practical ability, thus accelerating the college teaching reform of electronic information specialty. 


\section{ACKNOWLEDGMENT}

This work was financially supported by the Shandong Province Education Science "13th Five-Year" Program (BYGI2017012), Education Reform Project of Shandong Management University (JG2016-22), the Key Laboratory of Public Security Management Technology in Universities of Shandong (Shandong Management University) and 2016 Shandong Undergraduate Colleges and Universities Teaching Reform Research Project.

\section{REFERENCES}

[1] Y. Zhou, G. Wang and T. Xu, "Teaching reform and practice of applied innovative talents training in local colleges", China Academic Journal Electronic Publishing House, vol. 1, pp. 1004-3667, 2009. (In Chinese)

[2] Y. Ding, G. Zhang, H. Li, W. Li and J. Rong, "Research and exploration of engineering applied talents in electronic information specialty", Laboratory Science, vol. 19, pp. 236-240, 2016. (In Chinese)

[3] Z. Xiao, J. Wu, B. Shi, C. Guo and H. Li, "Research on the practice teaching mode of electronic information class undergraduate programs based on school-enterprise cooperation", Education Teaching Forum, vol. 34, pp. 43-45, 2017. (In Chinese)

[4] Y. Wang, L. Qian, W. Zhang, Z Mo and R. Zeng, "Construction research and practice on the teaching system of electronic information engineering driven by project", Kaoshi Zhoukan, vol. 6, pp. 1673-8918, 2016. (In Chinese)

[5] Y. Ma, J. Zuo, Q. Zhang, D. Cui and X. Lv, "Encountering problems and Countermeasures on innovative experimental team construction for students of electronic specialty", Education Teaching Forum, vol. 7, pp. 223-224, 2016. (In Chinese)

[6] D. Hamachek, Characteristics of Good teachers and Implications for Teacher Education, Phi Delta Kappan. pp. 341-345, 2015.

[7] B. Zhang, "Training pathways and methods of teachers' teaching ability", Theory and Practice of Education, vol. 12, pp. 39-40, 2008. (In Chinese) 